\title{
Rzemieślnicze dokumenty zawodowe - treść, kształt, wyraz graficzny, funkcje użytkowe i estetyczne
}

Rzemieślniczy dokument nie doczekał się do tej pory szczególniejszej uwagi badaczy. Wzmianki o tym, że na różnych etapach szkolenia zawodowego w ciagu minionych wieków tworzyła się specjalna grupa akt z nim związanych pojawiają się w bogatej literaturze przedmiotu ${ }^{1}$ oraz $w$ dokumentach prawnych regulujących sprawę kształcenia. Same zaś stanowią części zespołów akt przechowywanych w archiwach, bibliotekach ${ }^{2}$, wymieniane są również w starych inwentarzach cechowych. W końcu XIX i w początkach XX w. rozpoczęto ich zbieranie i wystawianie w muzeach ${ }^{3}$, jednak do tej pory w zbiorach placówek muzealnych stanowią marginalną część kolekcji. Inaczej jest w Muzeum w Rybniku ${ }^{4}$ Tu znajduje się spora ilość różnorodnych akt związanych z procesem kształcenia uczniów, egzaminami czeladniczymi i mistrzowskimi oraz prowadzącymi je komisjami egzaminacyjnymi ${ }^{5}$. Wybór padł na te, które najbardziej zainteresowani, czyli czeladnicy i

${ }^{1}$ Niemal w każdym opracowaniu związanym z historią rzemiosła, przewija się sprawa nauki zawodu. Przy tej okazji wspomina się o prowadzonych w cechach księgach wpisu, o wymaganych statutowo np. listach "dobrego urodzenia". Mówi się o dokumentach czeladniczych i mistrzowskich, nie poświęcając jednakże większej uwagi zawartym w nich treściom, kształtowi i formie. Niniejsza wypowiedź jest próbą zasygnalizowania niewyzyskanego do tej pory zespołu zabytków, jednorodnego pod względem funkcji użytkowych, lecz niosącego ważne przesłania kulturowe.

${ }^{2}$ Przykładowo w zbiorach specjalnych Wojewódzkiej Biblioteki Publicznej im H. Łopacińskiego w Lublinie w zespole sygn. RKP 1397 znajduje się blankiet świadectwa czeladniczego wystawianego przez cechy lubelskie przed rokiem 1864 .

${ }^{3}$ Ł. Charewiczowa, Muzeum Historyczne miasta Lwowa. Lwów 1936, s. 51.

${ }^{4}$ Rybnickie muzeum od 1980 r. specjalizuje się w gromadzeniu archiwaliów i zabytków, związanych nie tylko z rzemiosłem na Górnym Śląsku. W zbiorach Działu Historii Rzemiosła oprócz dokumentów, fotografii, pieczęci gromadzone są także weksylia cechowe oraz urządzenia, narzędzia i wyroby różnych rzemiosł.

${ }^{5}$ Najstarsze dokumenty rzemieślnicze w zbiorach muzeum pochodzą z pocz. XIX w., najmłodsze z pocz. lat dziewięćdziesiątych XX w. W ich skład wchodzą: wpisy do ksiąg cechowych, świadectwa czeladnicze i mistrzowskie, książeczki czeladnicze, korenspondencja związana z powołaniem członków komisji egzaminacyjnych czeladniczych i mistrzowskich z okresu międzywojennego, podręczniki i poradniki egzaminacyjne, fotografie. Szczególnie interesujące są zespoły dokumentów osobowych związanych z egzaminami czeladniczymi, które miały miejsce w sierpniu 1939 r., ponieważ zawierają komplety wymaganych świadectw szkolnych i zaświadczeń zawodo- 
mistrzowie otrzymywali do ręki, jako dokument urzędowo stwierdzający ich sprawność zawodową. Tak więc pod uwagę wzięto świadectwa mistrzowskie, książeczki i świadectwa czeladnicze niezależnie od nazwy jaką je obdarzono ${ }^{6}$.Wymienione dokumenty sporządzone zostały w XIX wieku i w pierwszych prawie czterdziestu latach wieku XX. Reprezentują, z wyjątkiem Pomorza, ziemie polskie znajdujące się w granicach wszystkich zaborów ${ }^{7}$.

Dyplom rzemieślniczy powstając w kancelarii cechowej, później Izbie Rzemieślniczej, w oparciu o odpowiednie uregulowania prawne ${ }^{8}$ stwierdza zdobycie wykształcenia zawodowego. Posługuje się przy tym pewnym ustalonym tradycją wzorem. Jego istotą jest przekaz werbalny; ikonografia pełni rolę posiłkową, stając się nie tylko graficznym dodatkiem - czasem żyje własnym życiem.

Rozpatrując przekaz słowny zauważa się, że z niewielkimi różnicami świadectwa czeladnicze zawierają:

- dane osobowe czeladnika (imię i nazwisko, data i miejsce urodzenia, często $\mathrm{z}$ oznaczeniem powiatu)

- u kogo się uczył

- czas nauki

- sprawowanie

- wyniki egzaminu teoretycznego i praktycznego

- apel do cechów o pomoc w dalszym kształceniu czeladnika

- zobowiązanie własne cechu do otaczania młodych pomocą

- formuła uwierzytelnienia z pieczęcią

- podpisy członków komisji ${ }^{9}$.

wych, opłat, zdjęć itp. jakie były wymagane od kandydatów w tym okresie. Sporo jest również dokumentów z okresu okupacji.

${ }^{6}$ Najczęściej spotykane nazwy dokumentów to: Świadectwo czeladnicze, Świadectwo wyzwolenia, Świadectwo nauki, Świadectwo nauki i złożenia egzaminu, List uczniowski i Świadectwo egzaminowe, Lehrbrief, Gesellenbrief, Prüfungzeignis, Prüfungzeignis und Lehrbrief, Attest mistrzowski, Świadectwo na mistrza.

${ }^{7}$ Podczas przygotowania referatu korzystano z rezultatów kwerendy przeprowadzonej w muzeach polskich, stąd obok muzealiów rybnickich pojawiają się również, choć sporadycznie, zabytki z innych muzeów.

${ }^{8}$ Dawne statuty obowiązujące indywidualnie w cechach straciły moc prawną po wprowadzeniu praw przemysłowych w Austrii, Niemczech i Rosji.W 1918 r. na obszarze niepodległego państwa polskiego obowiązywały trzy różniące się ustawy dotyczące rzemiosła: w byłej Galicji i na Śląsku Cieszyńskim - austriacka ustawa przemysłowa z 1. 1905-1907 (Spisz i Orawa miały przepisy węgierskiej ustawy austriackiej); w Poznańskiem, na Pomorzu i Górnym Śląsku - niemiecka ustawa przemysłowa z 1869 r. z późniejszymi nowelizacjami; w byłym zaborze rosyjskim - rozporządzenia księcia namiestnika Królestwa Polskiego z 1816 r. Jednolite polskie prawo przemysłowe zaczęło obowiązywać na terenie państwa od 7 czerwca 1927 r., z wyjątkiem Górnego Śląska, gdzie przepisy weszły w życie dopiero 1 lipca 1933 r. Wówczas też przestała obowiązywać na Śląsku Cieszyńskim ustawa austriacka.

${ }^{9}$ Treść formularzy świadectw wynika z rozwiązania przyjętego w cechu (Izbie Rzemieślniczej). Dla porówniania formularze: z Lublina z poł. XIX w. (por. przyp. 2), Lwowa z $1908 \mathrm{r}$. (MRy/RH/1861) i Katowic z 1924 r. (MRy/RH/1513). Synaturą MRy/RH/ oznaczono dokumenty z Muzeum w Rybniku. 
Zdarza się, iż podany jest rysopis czeladnika ${ }^{10}$, a także stwierdzenie że, „przez ten czas wiernie, pilnie, spokojnie i uczciwie....... jak każdemu czeladnikowi przystoi......." sprawował się lub, zwłaszcza w okresie międzywojennym, określa się jego postępowanie jako wzorowe, dobre, czasem dostateczne.

\section{1/ "URZĄD STARSZYCHI ZGROMADZENIAI W MIEŚCIE GUBERNIALNEM LUBLINIE.I}

Mając sobie na posiedzeniu dzisiejszem przez J.P. Członka Zgromadzenia swego przedstawione: iż Młodzieniec. rodem z miasta, wsi Guberni. Kraju.....

który w dniu. Mca.. Roku 18. jako Uczeń w Księgę kunsztu naszego zapisanym został, liczący teraz lat........wieku swego, odbył u niego naukę (z przykładnościa) tak, iż powodowany dobrem onegoż sprawowaniem się i okazaną przychylnością, życzeniem jego jest wyzwolić wspomionego Młodzieńca (darując mu od czasu umówionego nauki lat........ kwartał........ miesięcy...........). Gdy Urząd Starszych z examinu............. Uczniem w skutku Art.: 48 i 49 Postanowienia I. O. Xięcia Namiestnika Królewskiego z dnia 31 Grudnia 1816 roku odbytego, przekonywa się, iż co do Kunsztu, Sztuka Czeladnicza przez niego bez cudzej pomocy zrobiona, mianowice. .jest dokładną (na pochwałę zasługuje), że Młodzieniec ten posiada potrzebne wiadomości religijne, oraz czytania, pisania... zgoła, że jest dobrych Obyczajów; więc w zupełnym przychyleniu się do wniosku J. P. Członka Zgromadzenia swego, niniejszem wspomnionego Młodzieńca od obowiązków Ucznia odtad uwalniając, na Czeladnika wyzwala, i takim go mianuje ku dalszej legitymacyi przy wyciśnieniu Pieczęci Urzędu swego, niniejsze Zaświadczenie udzielając.

Działo się w Mieście Gubernialnem Lublinie na Posiedzeniu Zgromadzenia.

Kommissarz Municypalny

Zaświadczenie wyzwoleń na czeladnika służące J. P. Mca............18..... roku. Starszy

Podstarszy

2/ Świadectwo nauki. Stanisław Dublewski urodzony we Lwowie 1 maja roku 1884; religii rzyms. katol. odbył naukę w zawodzie drukarskim jako uczeń na zecera we Lwowie w Drukarni Ludowej; a nabywszy w tym zawodzie dostatecznego wykształcenia, został dnia 6 lutego 1908 od dalszej nauki uwolniony i w poczet towarzyszy wpisany. W dowód czego podpisany przełożony Gremium drukarzy typograficznych, litograficznych i odlewaczy czcionek zatwierdza niniejsze świadectwo własnoręcznym podpisem i pieczęcią.

We Lwowie dnia 6 lutego 1908.

3/ Świadectwo. Uczeń Augustyn Greiner urodzony dnia 1.VII 1906 r. w Dubiensku powiat rybnicki wyuczył się od 1.XII. 1921 r. do 1.XII. 1924 r. u mistrza ślusarskiego pana Józefa Kowola w Rybniku i w Knurowie na kopalni RZEMIOSŁA ślusarskiego i złożył dziś według obowiązujących przepisów przed niżej podpisaną komisją egzaminacyjną egzamin na czeladnika ślusarskiego z postępem dobrym. W Rybniku, dnia 14.XII.1924.

Komisja egzaminacyjna przym. cechu ślusarskiego

Ławnik:

Na podstawie Przewodniczacy:

Ławnik

przede wszyste egzaminu wydajemy p. Aug. Greinerowi to świadectwo i upraszamy wszystkich, pełną wiarą w podobnara i udzielenie wymienionemu czeladnikowi pomocy w dalszem kształceniu się, co i my odobnych wypadkach jesteśmy gotowi chętnie uczynić.

był wzrostu miernego "List wędrowny” Ignacego Wesołowskiego, Kraków 19.06.1817 (MRy/RH/88), podaje że Będzin 4.05.1908, (MRy/RH/575), ${ }^{11} \mathrm{MRy} / \mathrm{RH} / 88$. 
Pod koniec XIX w. i w początkach XX obserwować można coraz częstsze przytaczanie podstawy prawnej wydania świadectwa, choć nie jest to regułą.

Istotnym jest również język używany do sporządzania dyplomów. Wiek XIX przynosi powszechne korzystanie $\mathrm{z}$ gotowych blankietów drukowanych dyplomów, w których miejsca przeznaczone na wpis wypełniano odręcznie atramentem. Blankiety, drukowane w miejscowych drukarniach ${ }^{12}$ były jedno, dwu, a nawet trójjęzyczne. O ile w Galicji dopuszczalne było użycie równorzędne języka polskiego i niemieckiego ${ }^{13}$, o tyle na sąsiednim Górnym Śląsku było to nie do pomyślenia. Wszystkie dokumenty zawodowe - cechy, a od 1900 roku Izba Rzemieślnicza w Opolu, wystawiała wyłącznie w języku niemieckim. Ta sytuacja trwała na Górnym Śląsku jeszcze jakiś czas po 1922 r. - powstała w tym roku Izba Rękodzielnicza w Katowicach wydała zdecydowaną walkę językowi niemieckiemu w praktyce cechowej wprowadzając nowe, własne wzory i formularze świadectw czeladniczych i mistrzowskich. Na Zaolziu język polski i czeski używane były osobno i łącznie zarówno w dokumencie jak i na pieczę$\mathrm{ci}^{14}$.

W zaborze rosyjskim używano języków: polskiego i rosyjskiego, najczęściej jako zapisów, występujących obok siebie w postaci kolumn. Zdarza się także, że na dyplomie znajdują się jednocześnie teksty w języku polskim, rosyjskim i niemieckim ${ }^{15}$ lub $\mathrm{w}$ języku polskim i niemieckim ${ }^{16}$. Czasami ukryta $\mathrm{w}$ bordiurze jest zgoda cenzury na druk.

Osobną kwestię stanowi uwierzytelnienie dokumentu pieczęcią. Obok pieczęci cechowych, coraz rzadziej woskowych i lakowych, na świadectwach występują pieczęcie miejskie np. Sławkowa, Łowicza ${ }^{17}$, a także specjalnych urzędników - komisarzy upoważnionych do uczestnictwa w egzaminach. Na przełomie wieków daje się zaobserwować zmniejszenie częstotliwości użycia pieczęci z godłem zawodowym na rzecz pieczęci tekstowych, szczególnie tych reprezentujących komisje egzaminacyjne. Po odzyskaniu niepodległości Izby Rzemieślnicze pełniące nadzór nad egzaminami używały pieczęci $\mathrm{z}$ ukoronowanym Orłem Białym najpierw wg wzoru z 1919 r., a później z 1927 r. ${ }^{18}$ Pojawiają się także na dyplomach jako elementy graficzne wzory orłów przedrozbiorowych.

12 Tylko nieliczne druki noszą znaki drukarni. W posiadanym zestawie daje się ich wyodrębnić 18. Obejmują teren całej Polski.

${ }^{13} \mathrm{~Np} . \mathrm{MRy} / \mathrm{RH} / 86, \mathrm{MRy} / \mathrm{RH} / 88$ są w j. polskim i niemieckim, MRy/RH/89 w j. niemieckim zaś MRy/RH/ 1861 w j. polskim.

${ }^{14} \mathrm{Na}$ Zaolziu i Śląsku Cieszyńskim przed i po 1918 r. występują dyplomy w j. niemieckim (np. MRy/RH/500), j. polskim i niemieckim (np. MRy/RH/1467), języku czeskim (np. MRy/RH/1486 z 1938 r.), j. polskim (np. MRy/RH/1474 z 1927 r., MRy/RH/1699 z 1923 r. z dwujęzycznymi pieczęciami).

${ }^{15} \mathrm{MRy} / \mathrm{RH} / 90 \mathrm{z} 1878 \mathrm{r}$.

${ }^{16} \mathrm{MRy} / \mathrm{RH} / 87 \mathrm{z} 1847 \mathrm{r}$.

${ }^{17} \mathrm{MRy} / \mathrm{RH} / 1700, \mathrm{MRy} / \mathrm{RH} / 1471$.

${ }^{18} \mathrm{~W}$ połowie lat trzydziestych XX w. używano w Izbach pieczęci owalnej z ukoronowanym orłem, pod którym znajdował się napis: IZBA I RZEMIEŚNICZA I w I......... 
Prawo przemysłowe Austrii, Niemiec i Rosji nakładało obowiązek wystawiania przez cechy nie tylko świadectw uzdolnienia, ale także wydawania czeladnikom książeczek, gdzie majstrowie zatrudniający wędrujących czeladników czynili stosowne wpisy ${ }^{19}$. Często owe książeczki funkcjonowały niezależnie od dyplomu, który nie stanowił ich integralnej części. Czasami - prawdopodobnie dla ułatwienia posługiwania się świadectwem i książeczką wiązano je ze sobą poprzez wklejenie poskładanego do formatu książeczki dyplomu lub też, jak w przypadku późniejszych, bo z lat trzydziestych XX w. książeczek czeladniczych wydawanych przez Izbę Rzemieślniczą w Katowicach, w oprawie książeczki, przygotowano specjalną płócienną kieszonkę, w którą wkładano złożone świadectwa czeladnicze.

Same dyplomy, ze względu na dość spore rozmiary np. 42 x $59 \mathrm{~cm}$, choć nie zawsze, musiały być ze względów praktycznych wielokrotnie składane, często w dość skomplikowany sposób. Dla zabezpieczenia papieru, na którym znajdował się drukowany formularz świadectwa wprowadzono już w XIX w. dla jego wzmocnienia, podklejenie płótnem. Trwałości dokumentom dodawało także wklejenie druków w odpowiednio przygotowane introligatorsko oprawy. Te ostatnie, o rozmiarach ułatwiających ich przechowanie (ok. $17 \times 12 \mathrm{~cm}$ ), prawie zawsze z tłoczonym, często złoconym tytułem, suchą pieczęcią lub ozdobnikami, kryły różnorodne warianty wielkości, mocowania i składania druków świadectw.

Obok dokumentów zawodowych, czeladniczych i mistrzowskich, wystawiane były także takie, które można określić jako reprezentacyjne. Drukowane zazwyczaj na grubszym papierze lub kartonie, z bogatszą, kolorową szatą graficzną, dawały możliwość umieszczenia ich w oszklonych ramach ${ }^{20}$. Tak przygotowane, zawieszano w warsztatach jako certyfikaty potwierdzające umiejętności mistrza.

Sygnalizowane wyżej zagadnienia związane są ze stroną formalno-prawną świadectw czeladniczych i mistrzowskich, wskazując na ich funkcję czysto użytkową. Przede wszystkim są uwierzytelnionym przez upoważnione instytucje świadectwem sprawności zawodowych. Podjęcie pracy, nie tylko w warsztatach rzemieślniczych, wymagało ich przedstawienia pracodawcy dla dokonania wpisu o zatrudnieniu i zwolnieniu, stąd format dokumentów musiał być dostosowany do warunków codziennego użytkowania z zachowaniem środków koniecznych dla ich zabezpieczenia przed zniszczeniem.

Uzyskanie świadectwa czeladniczego czy mistrzowskiego od strony prawnej kończyło etap edukacji rzemieślnika, natomiast nie kończyła się, a właściwie ${ }^{19}$ Wcześniej w użyciu były karty, w końcu XVIII - pocz. XIX w. już drukowane, na których
mistrzowie robili wpisy o czasie zatrudnienia wędrującego czeladnika oraz jego sprawowania się. Ignacego West Kunszaft wystawiony przez Cech Introligatorów w Krakowie 19.06.1817 r. dla Kalisza Wesołowskiego, na którym znajdują się wpisy mistrzów np. z Poznania, Częstochowy, za - MRy/RH/88.

MRy/RH/542, 1099. 
dopiero rozpoczynała kolejna funkcja dyplomu. Wiąże się ona $\mathrm{z}$ samodzielnym życiem i oddziaływaniem na odbiorcę tego, co zostało zakodowane w warstwie ikonicznej dyplomu. Otóż płaszczyzna karty organizowana jest nie tylko przez słowo. Towarzyszą mu znaki wypływające ze sprawowania przez państwo nadzoru nad procesem kształcenia zawodowego - czyli godło państwowe ${ }^{21}$, wizerunki władców ${ }^{22}$, pieczęcie, znaczki skarbowe, opłaty stemplowe - nawet już w postaci nadruku na formularzu. Bordiury $\mathrm{z}$ rozbudowanych kartuszy $\mathrm{z}$ realistycznymi przedstawieniami narzędzi i wyrobów, prezentują różnorodność zajęć rzemieślniczych ${ }^{23}$. Figury mitologiczne ${ }^{24} \mathrm{i}$ alegoryczne ${ }^{25}$, niosące wzniosłe przesłania mają czasami podtekst patriotyczny i religijny. Zmuszają do zastanowienia sentencje mówiące o pracy ${ }^{26}$, o umiejętnościach i pożytkach z niej płynących. Poprzez ryciny $\mathrm{z}$ widokami miast ${ }^{27}$ wiąże się wspomnienie właściciela dokumentu z miejscem jego wystawienia, stwarza się także okazję ogląającemu do poznania nowych miejscowości. Ważną sprawą jest również użycie koloru zarówno w tekście, jak i w zdobiących go winietach i bordiurach. Wszystko to razem, ma za zadanie nie tylko uatrakcyjnić wygląd dyplomu, ale zrealizować

${ }^{21}$ Na dyplomach sprzed 1918 r. widoczny jest szeroki wybór graficznych rozwiązań herbów Austrii, Niemiec i Rosji. Pojawia się stylizowany austriacki dwugłowy orzeł z berłem i mieczem oraz jabłkiem w szponach; dwugłowy rosyjski orzeł - najpierw z tarczą z Orłem Białym na piersi, później po powstaniu styczniowym zepchnięty na jedno ze skrzydeł; silnie zarysowany niemiecki czarny orzeł z powtórzeniem wizerunku na tarczy na piersi. Po odzyskaniu niepodległości pojawia się polski orzeł w koronie wykonany wg wzorów z 1919 i 1927 roku, choć jako fragment bordiury przyjmuje zgodny z nią stylowo charakter.

22 Przykładem może być dyplom z podobizną cesarza Franciszka Józefa (MRy/RH/1916), bądź pełniące podobną funkcję monogramy: Fryderyka Wilhelma (MRy/RH/92) i cara Mikołaja I (MRy/RH/1498).

${ }^{23}$ Godła rzemiosł mniej lub bardziej stylizowane, różniące się od siebie ilością i konfiguracja narzędzi i wyrobów układane są w ciągi ramujące najczęściej tekst. Towarzyszą im dodatkowe ozdobniki w postaci np. gałęzi, liści wawrzynu i dębu, gryfów, architektury, alegorii. Czasami zastępowane są w winietach dowolną, samoistną kompozycją narzędzi i wyrobów.

${ }^{24}$ Merkury i Fortuna zdobią dyplomy wystawione przez cech w Bielsku w 1. 1924 i 1931 (MRy/RH/1460, 1701).

${ }^{25}$ Szczególnie bogate $w$ alegorie są dyplomy czeladnicze i mistrzowskie wystawione przez Izbę Rzemieślniczą w Opolu na pocz. XX w. (MRy/RH/19, 1488, 547).

${ }^{26}$ „Pilność i praca naród wzbogaca” i „Szczęść Boże” (MRy/RH/542) „Praca uszlachetnia”, „Oszczędność i praca ludzi zbogaca” (MRy/RH/422) to dewizy pojawiające się w okresie międzywojennym. Wierszyk „Mistrzem dopiero kto wymyślit coś, I Pomocnikiem kto zdziatat coś, Uczniem, każdy ktoś" na świadectwie wystawionym we Frysztacie (MRy/RH/1472 z 1927 r.) ma swój niemiecki odpowiednik na wcześniejszych świadectwach opolskich (np. MRy/RH/23). Tam również dewiza: Kunst bringt Gunst. Inne przykłady np. na świadectwach MRy/RH/89, 547.

27 Widoki miast: Opola (MRy/RH/23), Będzina (MRy/RH/575), Opawy (MRy/RH/500), Krakowa (MRy/RH/88), Lublina (ML/H/209, 1773, 1812 - Muzeum Lubelskie Oddział Historil miasta Lublina) to przykłady wykorzystania różnych technik graficznych. Ostatni, lubelski, pokazuje jak można tę samą bordiurę z rozległą panoramą miasta u góry, ale zmieniającymi się w medalionach budowlami charakterystycznymi dla miasta, wykorzystać w zmieniających się realiach politycznych lat 1906 i 1917-1918. 
konkretny program ideowy, edukacyjny i wychowawczy, działając również stymulująco na wyobraźnię i odczucia estetyczne.

Cóż mógł myśleć w 1817 r., przeciętny czeladnik mając w rękach dyplom z pięknie graficznie zakomponowanym widokiem Krakowa, rytowanym przez wiedeńczyka ${ }^{28}$, a także $\mathrm{z}$ nagromadzonymi w pozornym nieładzie przedmiotami. Dla posiadającego go czeladnika mógł być źródłem inspiracji do tworzenia rzeczy tak pięknych jak na winiecie, dla majstrów zatrudniających go i odnotowujących fakt jego pracy w różnych miejscowościach, był źródłem poznania dawnej stolicy. Podobne, jak się wydaje, były intencje umieszczania na świadectwach czeladniczych wystawianych przez Izbę Rzemieślniczą w Opolu w pocz. XX w. widoków siedziby Rejencji oraz ratusza w Opolu, czy w formularzach książek czeladniczych, świadectw czeladniczych i mistrzowskich widoku budynku, który Izba Rzemieślnicza w Katowicach nabyła w 1934 r. na siedzibę ${ }^{29}$

Wyraźny program ideowy ma także dyplom z lat dwudziestych XX w. projektowany przez Feliksa Łopieńskiego. ${ }^{30} \mathrm{~W}$ przestrzeni pomiędzy kolumnami renesansowej fasady, pod tekstem, widoczne są zarysy zamku królewskiego w Warszawie, kolumny Zygmunta oraz kościoła jasnogórskiego. W attyce, pod Okiem Opatrzności, pojawiają się: ukoronowany Orzeł Biały, Matka Boska Częstochowska, po bokach zaś postacie św. Wojciecha i Stanisława, a w płycinach pomiędzy kolumnami cztery sceny z podobiznami najsłynniejszych Polaków zajmujących się rzemiosłem: Piasta Kołodzieja, Wita Stwosza, Zygmunta III Wazy i Jana Kilińskiego. Bardzo podobny do wspomnianego, jest inny dyplom, również drukowany w Warszawie w tym samym czasie, wg projektu Martina $^{31}$. Pojawia się tu również brama, tym razem barokowa; jednak w przeciwieństwie do poprzedniej, kartusze z godłami rzemiosł wzbogacają górną i dolną partię bramy, a dewizy „Oszczędność i praca ludzi wzbogaca” i „W jedności sita" - boczne. Centralne miejsce zajmują godło państwa i herb Sosnowca.

Silnie oddziaływują na poczucie własnej wartości dyplomy wydawane w początkach XX w. przez Izbę Rzemieślniczą w Opolu. Jakże docenionym czuł się świeżo mianowany mistrz patrząc na świadectwo ze sceną nadania dyplomu przez panującego ${ }^{32}$, nawiązujący klimatem do tradycji średniowiecza i renesansu, czy też otrzymując dyplom z wytwornie odzianym majstrem wskazującym na tarczę z herbem Śląska, powyżej którego widoczna jest pszczoła - symbol pracowitości ${ }^{33}$.

Środki wyrazu stosowane przez projektantów lub wykonawców dyplomów, nawet w swym najskromniejszym kształcie, uwzględniają funkcjonowanie psy-

${ }^{28}$ Dyplom wg projektu Johanna Renarda z Wiednia wykonała drukarnia F. Frydleina w Kra(MRy/RH/88).

${ }^{29} \mathrm{MRy} / \mathrm{RH} / 1874 / 1-2$

MRy/RH/421, 1471

${ }^{31} \mathrm{MRy} / \mathrm{RH} / 422$.

${ }_{33}^{32}$ MRy/RH/19.

MRy/RH/500. 
chiki ludzkiej. Poprzez doznania wzrokowe przyswajane są treści pożądane przez wystawców świadectw: związanie środowiska rzemieślniczego z władzą państwową, zakorzenienie w tradycji, identyfikację $\mathrm{z}$ efektami dobrze wykonanej pracy, a w konsekwencji osiągnięcie odpowiedniej pozycji i prestiżu w hierarchii zawodowej i społecznej. Dla współczesnego odbiorcy, zwłaszcza badacza, są cennym źródłem poznania nie tylko gustów artystycznych epoki, dają także wgląd w to, co próbowano zrobić ze świadomością. 